\title{
Diagnostic molecular markers and the genetic relationships among three species of the Cheilosia canicularis group (Diptera: Syrphidae)
}

\author{
Vesna MILANKOV ${ }^{1}$, Jelena STAMENKOVIĆ ${ }^{1}$, Jasmina LUDOŠKI ${ }^{1}$, Gunilla STÅHLS² and ANTe VUJIĆ ${ }^{1}$ \\ ${ }^{1}$ Department of Biology and Ecology, University of Novi Sad, Trg Dositeja Obradovića 2, 21000 Novi Sad, Serbia and Montenegro; \\ e-mail: vesnam@ib.ns.ac.yu \\ ${ }^{2}$ Finnish Museum of Natural History, PO Box 17, FIN-00014 University of Helsinki, Finland
}

Key words. Allozymes, mtDNA, genetic differentiation, genetic variability, Cheilosia, canicularis, Cheilosia himantopus, Cheilosia orthotricha

\begin{abstract}
To re-evaluate the taxonomic status of Cheilosia canicularis (Panzer, 1801), C. himantopus (Panzer, 1798) and C. orthotricha Vujić \& Claussen, 1994, variation in the mitochondrial DNA (mtDNA) sequence of the cytochrome $c$ oxidase subunit I (COI) gene and 18 nuclear allozyme genes were surveyed in allopatric and sympatric populations from Serbia and Montenegro. Genetic relationships among five populations of these species from the Fruška Gora (Serbia), Kopaonik (Serbia) and Durmitor (Montenegro) mountains were analyzed. Seven allozyme loci (Aat, Aco, Fum, Idh-1, Idh-2, Mdh-2 and Sdh) were diagnostic for delineating C. orthotricha from the other two species, while only a low, but consistent, genetic differentiation was observed between $C$. canicularis and $C$. himantopus. Differentiating all three species was possible based solely on the species-specific alleles at the Est-? locus. Sequence comparisons of $738 \mathrm{bp}$ of the COI gene from eleven specimens was consistent with the variability in nuclear allozymes. Sequence data revealed variation in $5 \%$ of the nucleotide sites among $C$. orthotricha and the $C$. canicularis/C. himantopus pair, while less variation $(0.68 \%)$ was observed within the pair C. canicularis/C. himantopus. However, the presence of one diagnostic allozyme locus and five consistently variable nucleotide sites in sympatric populations of C. canicularis and C. himantopus (Durmitor, Montenegro) suggest that these two species have separate gene pools.
\end{abstract}

\section{INTRODUCTION}

Cheilosia s. str. Meigen, 1822 (Diptera: Syrphidae) includes a recently defined group of five taxa closely related to the species Cheilosia canicularis (Barkalov, 2002). The $C$. canicularis complex of species comprises C. canicularis (Panzer, 1801), C. himantopus (Panzer, 1798), C. orthotricha Vujić \& Claussen, 1994, C. japonica Herve-Bazin, 1914, and C. yesonica Matsumura, 1905, and was formed in 1994 after the description of $C$. orthotricha (Vujić \& Claussen, 1994). Cheilosia himantopus was re-established as a valid species by Stuke \& Claussen (2000) after detailed study of the morphological variability and ecology of both adult and immature specimens. The species $C$. japonica and $C$. yesonica occur in Japan, while the other three have wider distributions in the Palaearctic region (Peck, 1988). Adults inhabit deciduous and evergreen forest habitats and clearings along streams and rivers (Stuke \& Claussen, 2000; Speight, 2003; Vujić \& Šikoparija, 2001). The immature stages of $C$. canicularis and $C$. himantopus develop in stems, leaves and rhizomes of Petasites spp. (Stuke \& Claussen, 2000; Speight, 2003; Vujić \& Šikoparija, 2001). Females of $C$. canicularis have been observed to oviposit on leaves surrounding flower buds or on leaf buds in late summer or early autumn and those of $C$. himantopus on leaf buds in late spring (Vujić \& Šikoparija, 2001). The larvae of C. orthotricha develop in flower stems of Petasites hybridus (Stuke \& Claussen, 2000) and pupate in the rhizome or in the vicinity of the host plant.
The taxonomic status of $C$. canicularis has been a subject of debate ever since its description. This resulted in a number of synonyms (Vujić \& Claussen, 1994; Stuke \& Claussen, 2000) and discussions about its systematic relationship with $C$. himantopus. After defining $C$. orthotricha (Vujić \& Claussen, 1994) as a species, the study of the canicularis group intensified (Stuke, 1995, 2000; Stuke \& Brückner, 2001; Stuke \& Claussen, 2000; Vujić, 1996). A study of the phylogenetic relationships of 57 Cheilosia species, using a large 1128 bp fragment of the COI gene in a separate parsimony analysis, combined with a sequence fragment of the nuclear 28S rRNA gene, always revealed a monophyletic clade ( $C$. orthotricha + (C. canicularis $+C$. himantopus)) (Ståhls et al., 2004). Diagnostic characters of adults (length of aristal hairs, specific hypandrium structure and distribution of pilosity on tergites III and IV in females; Stuke \& Claussen, 2000) and larvae and pupae (Stuke, 2000) indicated that the separation of the closely related species C. himantopus and $C$. canicularis and the species $C$. orthotricha was defendable, even if the exhibited levels of variation were low. In order to obtain data about the levels of variation in mtDNA, Stuke \& Brückner (2001) sequenced the mitochondrial cytochrome $c$ oxidase subunit II (COII) gene and parts of tRNA genes tLeu and tLys of a few specimens of allopatric $C$. canicularis and $C$. himantopus from Germany. However, the sample was too small to determine conclusively whether the two species were independent. Still, there are difficulties in discriminating between certain individuals of $C$. canicularis or $C$. himantopus and there are specimens in collections that 


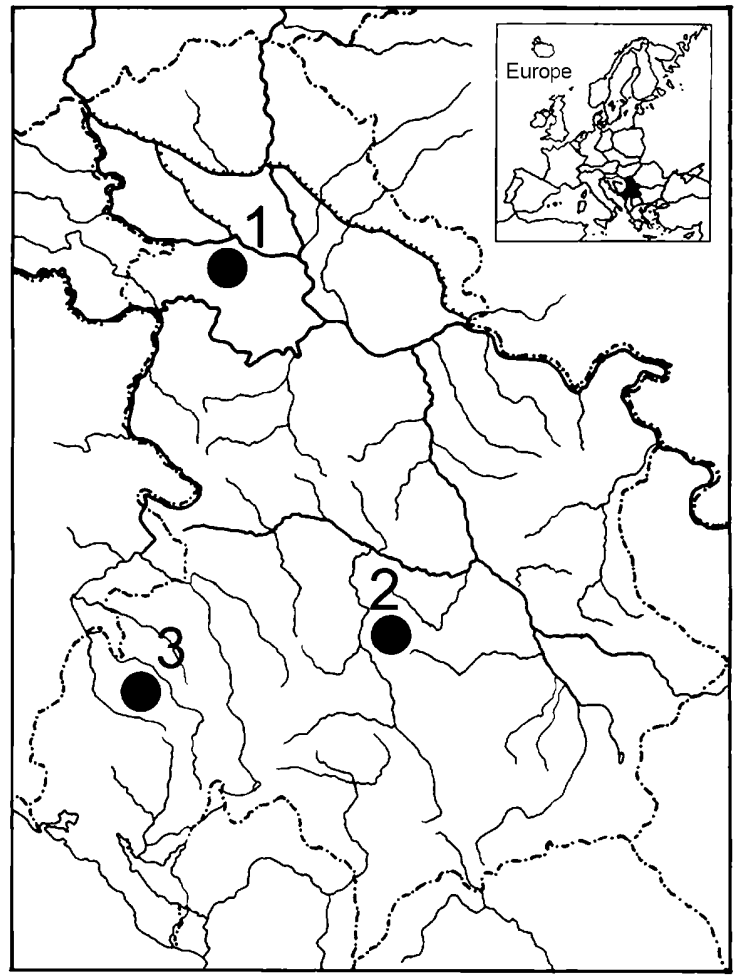

Fig. 1. Origins of populations of Cheilosia orthotricha, $C$. canicularis and $C$. himantopus analyzed for allozymes: 1 Fruška Gora, Serbia $\left(19^{\circ} 50^{\prime} \mathrm{E}, 45^{\circ} 10^{\prime} \mathrm{N}\right) ; 2$ - Kopaonik, Serbia $\left(20^{\circ} 40^{\prime} \mathrm{E}, 43^{\circ} 15^{\prime} \mathrm{N}\right) ; 3$ - Durmitor, Montenegro $\left(19^{\circ} 00^{\prime} \mathrm{E}\right.$, $\left.43^{\circ} 11^{\prime} \mathrm{N}\right)$

cannot be identified as one or the other taxon (Vujić \& Šikoparija, 2001). It has been hypothesized that the taxon is one species with two generations (Vujić \& Claussen, 1994) or it is indeed two independent species (Stuke \& Claussen, 2000).

Given this taxonomic dilemma and the distribution of the focal taxa in similar habitats, a more detailed analysis of the biology (Vujić \& Šikoparija, 2001) and intra- (Stamenković et al., in press) and interpopulation analysis of genetic variability are necessary. Thus, the objective of this paper was three-fold: (1) to analyze using allozymes the population-genetic variability in sympatric and allopatric populations of $C$. orthotricha, $C$. canicularis and $C$. himantopus, (2) to investigate the pattern of variation in the COI sequences, and (3) to validate or invalidate the status of the controversial species $C$. canicularis and $C$. himantopus.

\section{MATERIAL AND METHODS}

\section{Sample collection and identification}

The species $C$. japonica and $C$. yesonica were not available for DNA analysis. Samples of the species Cheilosia orthotricha, C. canicularis and C. himantopus were collected from Fruška Gora (hilly area in the Pannonian plain) and two high Dinaric mountains, Durmitor and Kopaonik, in Serbia and Montenegro (Fig. 1, Table 1). Specimens were stored at $-20^{\circ} \mathrm{C}$ until used in the analysis.

Species identification, prior to preparation of whole body tissue extracts, was based on the morphological taxonomic characters defined for the Cheilosia canicularis complex of species (Stuke \& Claussen, 2000), such as arista characteristics in males and females, distiphallus in males and tergites III and IV in females. Black hairs on mesonotum in females served as an ancillary trait for delineating $C$. canicularis (black hairs present) and $C$. himantopus (no black hairs in populations from the Balkans).

\section{Allozyme analysis}

All populations were included in the allozyme analysis in order to determine molecular markers that could be used to identify the taxa studied. Due to the small number of specimens, populations COKOP and CHFG were not included in the population - genetic analysis, and genetic differentiation was quantifiable based only on COFG, CCDUR, CHDUR and CHKOP (Table 1).

Genetic variability was studied by standard $5 \%$ polyacrylamide gel electrophoresis, following Munstermann (1979) (ACO, EST, FUM, GPD, GPI, HAD, HK, IDH, LDH, MDH, ME, PGM, SOD) and Pasteur et al. (1988) (AAT, SDH), with slight modifications (Milankov, 2001). The Tris-Boric-EDTA buffer system ( $\mathrm{pH}$ 8.9) was used to assay esterase (E.C. 3.1.1.? EST; locus Est-?), fumarate hydratase (4.2.1.2. FUM; Fum), glucosephosphate isomerase (5.3.1.9. GPI; Gpi), hexokinase (2.7.1.1. HK; two loci: $H k-2, H k 3)$, malic enzyme (1.1.1.40. ME; $M e$ ), phosphoglucomutase (2.7.5.1. PGM; Pgm), sorbitol dehydrogenase (1.1.1.14. SDH, $S d h$ ) and superoxide dismutase (1.15.1.1. SOD; Sod). A Tris-Citric buffer system ( $\mathrm{pH}$ 7.1) was used to assay aconitase (4.2.1.3. ACO; Aco), aspartate amino transferase (2.6.1.1. AAT; Aat), glycerol 3-phosphate dehydrogenase (1.1.1.8. GPD; Gpd-2), $\beta$-hydroxy acid dehydrogenase (3.1.1.31. HAD, $\mathrm{Had}$ ), isocitrate dehydrogenase (1.1.1.42. IDH; $I d h-1, I d h-2)$, lactate dehydrogenase (1.1.1.27. LDH, $L d h)$ and malate dehydrogenase (1.1.1.37. MDH; Mdh-1, Mdh-2).

Depending on the metabolic function and regional distribution of enzymes, different body parts were used for the analysis of isozyme variability (head in $0.2 \mathrm{ml}$ homogenate: AAT, FUM, $\mathrm{HAD}, \mathrm{LDH}, \mathrm{MDH}, \mathrm{ME}$; thorax in $0.3 \mathrm{ml}$ : ACO, EST, GPD, GPI, HK, IDH, PGM, SDH, SOD). Duration of electrophoretic run at $90 \mathrm{~mA}(135-220 \mathrm{~V})$ was 3-4 h.

TABLE 1. Population codes, based on the species and place of origin (number of specimens used for allozyme analysis in parenthesis) and collection dates.

\begin{tabular}{|c|c|c|c|}
\hline & Fruška Gora & Kopaonik & Durmitor \\
\hline C. orthotricha & $\begin{array}{c}\text { COFG (16) } \\
05 / 1996 ; 03 / 2000 ; 03 / 2001\end{array}$ & $\begin{array}{c}\text { COKOP (4)* } \\
04 / 2001 ; 05 / 2001\end{array}$ & - \\
\hline C. canicularis & - & - & $\begin{array}{c}\text { CCDUR (21) } \\
07 / 1998 ; 08 / 1999 ; 06 / 2000\end{array}$ \\
\hline C. himantopus & $\begin{array}{c}\text { CHFG (3)* } \\
\text { 04/1998; 04/2001 }\end{array}$ & $\begin{array}{c}\text { CHKOP (13) } \\
\text { 08/1997; 06/1998; 04/2001; 06/2001 }\end{array}$ & $\begin{array}{c}\text { CHDUR (15) } \\
06 / 1998 ; 05 / 2001 ; 06 / 2001 ; 06 / 2002\end{array}$ \\
\hline
\end{tabular}

\footnotetext{
* omitted from population-genetic analysis due to the small number of specimens
} 
TABLE 2. Allelic frequencies at 10 loci in populations of Cheilosia orthotricha, C. canicularis and C. himantopus (see Table 1 for population codes).

\begin{tabular}{|c|c|c|c|c|c|c|c|}
\hline \multicolumn{3}{|c|}{ Locus Allele COFG } & \multicolumn{5}{|c|}{ COKOP CCDUR CHDUR CHKOP CHFG } \\
\hline \multirow[t]{3}{*}{ Aat } & $a$ & 1.000 & 1.000 & - & - & - & - \\
\hline & $b$ & - & - & 1.000 & 1.000 & 1.000 & 1.000 \\
\hline & $\mathrm{n}$ & 16 & 4 & 14 & 9 & 9 & 2 \\
\hline \multirow[t]{3}{*}{ Aco } & $a$ & 1.000 & 1.000 & - & - & - & - \\
\hline & $b$ & - & - & 1.000 & 1.000 & 1.000 & 1.000 \\
\hline & $\mathrm{n}$ & 6 & 2 & 4 & 8 & 6 & 2 \\
\hline \multirow[t]{4}{*}{ Est-? } & $a$ & 1.000 & 1.000 & - & - & - & - \\
\hline & $b$ & - & - & 1.000 & - & - & - \\
\hline & $c$ & - & - & - & 1.000 & 1.000 & 1.000 \\
\hline & $\mathrm{n}$ & 16 & 4 & 17 & 10 & 9 & 2 \\
\hline \multirow[t]{3}{*}{ Fum } & $a$ & 0.889 & 1.000 & - & - & - & - \\
\hline & $b$ & 0.111 & - & 1.000 & 1.000 & 1.000 & 1.000 \\
\hline & $\mathrm{n}$ & 9 & 2 & 11 & 11 & 12 & 2 \\
\hline \multirow[t]{3}{*}{$I d h-1$} & $a$ & 1.000 & 1.000 & - & - & - & - \\
\hline & $b$ & - & - & 1.000 & 1.000 & 1.000 & 1.000 \\
\hline & $\mathrm{n}$ & 11 & 4 & 17 & 9 & 13 & 3 \\
\hline \multirow[t]{3}{*}{$I d h-2$} & $a$ & 1.000 & 1.000 & - & - & - & - \\
\hline & $b$ & - & - & 1.000 & 1.000 & 1.000 & 1.000 \\
\hline & $\mathrm{n}$ & 11 & 4 & 17 & 9 & 13 & 3 \\
\hline \multirow[t]{3}{*}{$\begin{array}{l}\text { Mdh- } \\
2\end{array}$} & $a$ & 1.000 & 1.000 & - & - & - & - \\
\hline & $b$ & - & - & 1.000 & 1.000 & 1.000 & 1.000 \\
\hline & $\mathrm{n}$ & 14 & 2 & 13 & 15 & 10 & 2 \\
\hline \multirow[t]{4}{*}{$M e$} & $a$ & - & - & 1.000 & 1.000 & - & 1.000 \\
\hline & $b$ & 0.833 & - & - & - & 1.000 & - \\
\hline & $c$ & 0.167 & 1.000 & - & - & - & - \\
\hline & $\mathrm{n}$ & 6 & 2 & 4 & 8 & 6 & 2 \\
\hline \multirow[t]{3}{*}{ Pgm } & $a$ & - & - & 0.095 & 0.500 & 0.143 & - \\
\hline & $b$ & 1.000 & 1.000 & 0.905 & 0.500 & 0.857 & 1.000 \\
\hline & $\mathrm{n}$ & 15 & 2 & 21 & 10 & 7 & 2 \\
\hline \multirow[t]{3}{*}{$S d h$} & $a$ & 1.000 & 1.000 & - & - & - & - \\
\hline & $b$ & - & - & 1.000 & 1.000 & 1.000 & 1.000 \\
\hline & $\mathrm{n}$ & 5 & 2 & 4 & 6 & 2 & 2 \\
\hline
\end{tabular}

The electrophoresis of individuals from different populations was conducted in the same gel for direct interspecific comparison. Loci were numbered and alleles marked alphabetically with respect to order of increasing anodal migration.

\section{Population -genetic analysis}

Statistical analysis of allozyme data was performed using the computer program BIOSYS-2 (Swofford \& Selander, 1981, modified by Black, 1997). The analysis included determining genotypic and allelic frequencies, the frequency of polymorphic loci $(P)$, and the mean observed and expected heterozygosity $\left(H_{o}, H_{e}\right)$, corrected using Levene's (1949) formula for small samples. The deviation between $H_{o}$ and $H_{e}$ of separate variable loci was evaluated using Wright's inbreeding coefficient $\left(F_{i}\right.$; Wright, 1951) and mean $F$-statistics (Weir, 1996). Nei's genetic identity (1978) was used to compare gene frequencies among species or populations, and to construct a dendrogram using
TABle 3. Deviation of genotype frequencies from HardyWeinberg equilibrium at polymorphic loci in populations of Cheilosia orthotricha, C. canicularis and C. himantopus.

\begin{tabular}{lccccc}
\hline Locus & Population & $H_{o}$ & $H_{e}$ & $F_{i s}$ & $P$ \\
\hline Fum & COFG & 0 & 1.882 & 1.000 & 0.0015 \\
Me & COFG & 0 & 1.818 & 1.000 & 0.0075 \\
Pgm & CCDUR & 0 & 3.707 & 1.000 & 0.0000 \\
& CHDUR & 0 & 5.263 & 1.000 & 0.0009 \\
& CHKOP & 0 & 1.846 & 1.000 & 0.0044 \\
\hline
\end{tabular}

$H_{o}=$ Observed number of heterozygosity; $H_{e}=$ Expected number of heterozygosity; $F_{i s}=$ Fixation index (Wright, 1951); $P=$ Level of significance.

clustering with the Unweighted Pair Group Method with Arithmetic Average (UPGMA) (Sneath \& Sokal, 1973) .

\section{DNA sequencing}

A total of ten specimens from all six populations (Table 1) and one specimen of C. canicularis from Sweden (Skåne, Fyledalen) were used for DNA sequencing. DNA was extracted from legs or other parts of single frozen individuals $\left(-20^{\circ} \mathrm{C}\right)$ using the Nucleospin Tissue DNA extraction kit (MacheryNagel, Düren, Germany) following the manufacturer's protocols and then re-suspended in $50 \mu 1$ of ultra-pure water. Amplification was attempted for COI and internal transcribed spacer region (ITS2) rRNA genes, but the latter was unsuccessful (probably due to the age of the specimens). Remains of specimens, including male genitalia, used for the morphological studies and for DNA extraction are deposited at the Finnish Museum of Natural History (Helsinki, Finland).

PCR reactions were carried out in $25 \mu 1$ reaction aliquots containing $2 \mu \mathrm{l}$ DNA extract, $1 \mu \mathrm{l}$ of each primer (at $10 \mathrm{pmol} / \mu \mathrm{l}$ ), $0.25 \mu \mathrm{l}$ of DNA polymerase $(5 \mathrm{U} / \mu \mathrm{l}), 2 \mu 12.5 \mathrm{mM} \mathrm{MgCl} 2,2.5 \mu \mathrm{l}$ $10 \times$ Buffer II (MBI Fermentas, St. Leon-Rot, Germany) and 4 $\mu 1200$ mM dNTP (GeneAmp, Applied Biosystems, Foster City, CA, USA) and ultra-pure water. Thermocycler conditions were initial denaturing at $95^{\circ} \mathrm{C} 2 \mathrm{~min}, 29$ cycles of $30 \mathrm{~s}$ denaturing at $94^{\circ} \mathrm{C}, 30 \mathrm{~s}$ annealing at $49^{\circ} \mathrm{C}, 2 \mathrm{~min}$ extension at $72^{\circ} \mathrm{C}$, followed by a final extension of $8 \mathrm{~min}$ at $72^{\circ} \mathrm{C}$. The universally conserved primers used for amplifying and sequencing the COI fragment (738-bp) were the forward primer C1-J-2183 (5'-CAA CAT TTA TTT TGA TTT TTT GG-3') (alias JERRY) and the reverse primer TL2-N-3014 (5'-TCC AAT GCA CTA ATC TGC CAT ATT A-3') (alias PAT) (Simon et al., 1994). PCR products were purified using the GFX PCR Purification Kit (GE Healthcare Biosciences, Little Chalfont, UK) and then sequenced (with the PCR primers) in both directions using the Big Dye Terminator Cycle Sequencing Kit (Applied Biosystems, Foster City, CA, USA) at one-fourth of the recommended volumes on an ABI PRISM 377 (Applied Biosystems, Foster City, CA, USA) semi-automated DNA sequencer. The sequences were edited for base-calling errors and assembled using Sequence Navigator ${ }^{\mathrm{TM}}$ (version 1.01) (Applied Biosystems, Foster City, CA, USA).

\section{RESULTS}

\section{Allozyme variability}

Diagnostic allozyme loci

Delineation of all three species was possible based only on allozymes coded by the alleles at the Est-? locus that were unique for the populations of $C$. orthotricha, $C$. canicularis and $C$. himantopus (Table 2). Alleles at 
TABLE 4. Estimates of genetic variability parameters in populations of Cheilosia orthotricha, C. canicularis and C. himantopus (standard error in parenthesis).

\begin{tabular}{lcccc}
\hline Population & $A(\mathrm{SE})$ & $H_{e}(\mathrm{SE})$ & $H_{o}(\mathrm{SE})$ & $P_{(0.95)}$ \\
\hline COFG & $1.1(0.1)$ & $0.026(0.018)$ & 0.000 & 11.1 \\
CCDUR & $1.1(0.1)$ & $0.010(0.010)$ & 0.000 & 5.6 \\
CHDUR & $1.1(0.1)$ & $0.028(0.028)$ & 0.000 & 5.6 \\
CHKOP & $1.1(0.1)$ & $0.014(0.014)$ & 0.000 & 5.6 \\
\hline
\end{tabular}

$A=$ Mean number of alleles per locus; $H_{e}=$ Expected heterozygosity averaged over all loci; $H_{o}=$ Average frequency of observed heterozygosity; $P_{(0.95)}=$ Frequency of polymorphic loci based on the 0.95 criterion.

another seven loci (Aat, Aco, Fum, Idh-1, Idh-2, Mdh-2, and $S d h$ ) were species-specific for $C$. orthotricha, and diagnostic for this species. All analyzed populations were identical at eight loci (Gpd-2, Gpi, Had, Hk-2, Hk-3, Ldh-2, Mdh-1 and Sod-1).

Population genetic structure analysis

Of the 18 isozyme loci analyzed, 15 were monomorphic within each of the populations analyzed. The Fum and Me loci were polymorphic only in COFG, and Pgm was variable in CCDUR, CHDUR and CHKOP (Table 2). Additionally, the spatial distribution of alleles at the Me locus among populations of $C$. himantopus was observed, with the one allele $\left(M e^{a}\right)$ in CHDUR and CHFG, and a different allele $\left(M e^{b}\right)$ in CHKOP, indicating genetic divergence among conspecific populations.

Only two alternative homozygotes $\left(F_{i s}=1.0\right)$, but no heterozygotes, were observed at any of the polymorphic loci within populations. Thus, the observed population structure deviated from the one expected in a randomly mating population (Table 3 ).

Frequency of polymorphic loci was highest in the COFG population, while the mean number of alleles was identical in all populations analyzed (Table 4).

\section{COI variation}

We obtained a 738 bp fragment of the COI gene, corresponding to nucleotide positions 2233 to 2970 in Drosophila yakuba sequence (Clary \& Wolstenholme, 1985). GenBank accession numbers of the analyzed specimens from six populations are: COFG (VM268-COI: AY800282; VM269-COI: AY800283), COKOP (VM312-COI: AY800284), CCDUR (VM248-COI: AY800280; VM249-COI: AY800281), CHKOP (VM298-COI: AY800285; VM299-COI: AY800286), CHDUR (VM305-COI: AY800287; VM306-COI: AY800288), CHFG (VM309-COI: AY800289). Sequences differed at 38 (5.15\%) and 37 (5.01\%) nucleotide sites between $C$. orthotricha and C. himantopus, and C. orthotricha and C. canicularis, respectively. Only five nucleotide sites $(0.68 \%)$ differed between $C$. canicularis and $C$. himantopus. The exception was a single specimen from the CHFG population (VM309), which varied from conspecifics in one nucleotide site and from C. canicularis at four sites (Fig. 2). Additionally, data presented herein were identical to the respective sequence data obtained for C. canicularis (Serbia: AY533365), C.
2222222222222222222222222222222222222222 2222233344445555566666666777788888888999 5678902656780333500123357223403557789556 2762411308174178306877812018447351422173

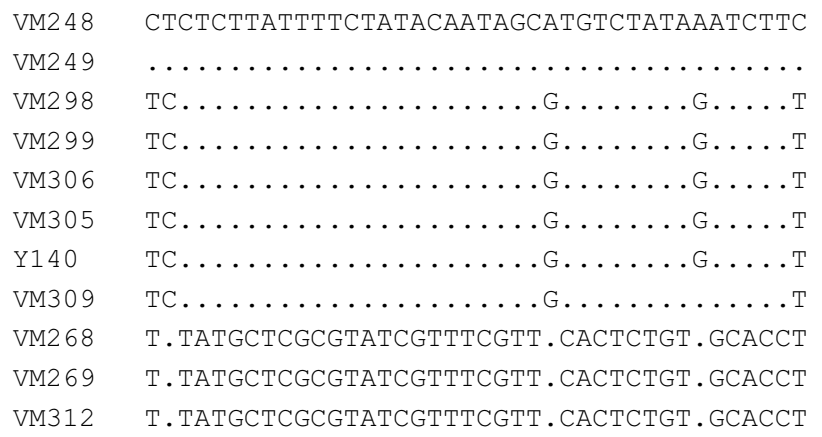

Fig. 2. Mitochondrial DNA sites (within the $738 \mathrm{bp}$ fragment spanning COI positions 2232-2970) that varied among populations of Cheilosia canicularis (CCDUR: VM248, VM249), C. himantopus (CHKOP: VM298, VM299; CHDUR: VM305, VM306; CHFG: VM309; Sweden, Skíne, Fyledalen: Y140) and $C$. orthotricha (COFG: VM268, VM269; COKOP: VM312).

himantopus (Montenegro: AY533352; Sweden, Skåne, 2004 not submitted) and C. orthotricha (Montenegro: AY533353) (Ståhls et al., 2004).

The majority of the sequence differences between $C$. orthotricha and the $C$. canicularis/C. himantopus pair were transitions rather than transversions $(62.16 \% \mathrm{TS}$, $37.84 \% \mathrm{TV} ; 63.16 \% \mathrm{TS}, 36.84 \% \mathrm{TV}$, respectively). All DNA substitutions between C. himantopus and C. canicularis were transitions (Fig. 2). The sequences were AT rich with a mean AT content of $73.62 \%$, while the $3^{\text {rd }}$ codon position exhibited an average AT content of $96 \%$.

\section{Interspecific relationships}

Genetic distance and genetic identity values (Nei, 1978) based on the 18 allozyme loci for the populations analyzed are shown in Table 5. A dendrogram of genetic relationships (Fig. 3) was constructed based on the average genetic identity values, using the UPGMA clustering method. The least genetic differentiation was registered between the conspecific populations CHDUR and CHKOP that formed a cluster. The highest degree of genetic difference was registered between the CCDUR and COFG populations.

The COI sequence of $C$. orthotricha was distinct (5.01\% to $5.15 \%$ nucleotide divergence) from those of $C$.

TABLE 5. Genetic distance (above diagonal) and genetic identity (below diagonal) calculated after Nei (1978) among populations of Cheilosia orthotricha, C. canicularis and $C$. himantopus.

\begin{tabular}{lcccc}
\hline Population & COFG & CCDUR & CHDUR & CHKOP \\
\hline COFG & $* * * * *$ & 0.672 & 0.708 & 0.586 \\
CCDUR & 0.511 & $* * * * *$ & 0.067 & 0.119 \\
CHDUR & 0.493 & 0.935 & $* * * * *$ & 0.065 \\
CHKOP & 0.557 & 0.888 & 0.937 & $* * * * *$ \\
\hline
\end{tabular}




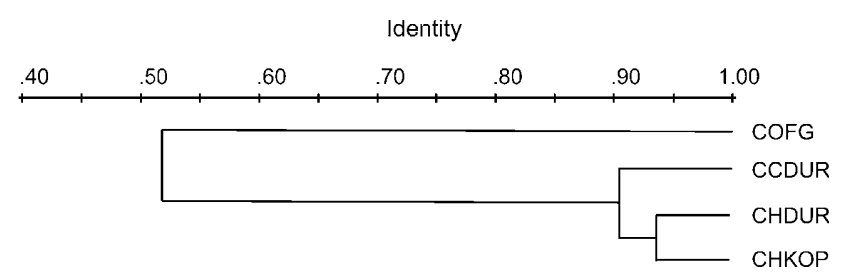

Fig. 3. Dendrogram of genetic relationships among populations of Cheilosia orthotricha, C. canicularis and C. himantopus using unweighted pair group clustering (Sneath \& Sokal, 1973) of Nei's, (1978) unbiased genetic identity, based on the allozyme data.

canicularis and C. himantopus. Pairwise uncorrected distances between the closely related species $C$. canicularis and C. himantopus were $0.54 \%$ and $0.68 \%$. The cladogram in Ståhls et al. (2004), and the parsimony analysis of $738 \mathrm{bp}$ of the 10 specimens from 6 populations of $C$. orthotricha, C. canicularis and C. himantopus (not shown) produced the same topology as the tree constructed using the allozyme data (Fig. 3).

\section{DISCUSSION}

\section{Genetic differences between species}

Morphological characters are often insufficient or not exclusive enough for identification of morphologically cryptic taxa in the family Syrphidae. However, allelic and genotypic differentiation of allozyme loci allowed successful delineation of numerous cryptic species of hoverflies (Milankov, 2001; Milankov et al., 2001). Although the diagnostic value of isozyme loci as criteria for defining degree of genetic differentiation and evolutionary independence is not the same for all loci, some patterns have been observed. The loci Aat, Fum, Hk-2, $H k-3$ and $M d h-2$, monomorphic in the majority of populations analyzed, were valuable diagnostic tools for species of Merodon with a high degree of genetic divergence (Milankov, 2001; Milankov et al., 2002c). On the other hand, loci that are frequently polymorphic and exhibit spatial variability, the Gpi, Had, Me, Pgm and Sod-1 loci, are important for identifying of closely related species of the same genus (Milankov, 2001; Milankov et al., 2002b, c).

In addition to unequivocal morphological characters (Vujić \& Claussen, 1994; Vujić \& Šikoparija, 2001) the eight diagnostic allozyme loci found in this study and mtDNA analysis, confirmed that $C$. orthotricha is indeed distinct from $C$. canicularis and $C$. himantopus. The loci Aat, Fum, Idh-1, Idh-2 and $M d h-2$, and for the first time analyzed in hoverflies, the loci Aco, Sdh and Est-? are diagnostic of $C$. orthotricha. Genetic identity values, similar to those of other species of the family Syrphidae (0.305-0.728; Milankov, 2001) and distinct pairwise distance in the COI mtDNA gene, clearly demonstrate the independent taxonomic status of $C$. orthotricha.

Only a low genetic differentiation was observed between Cheilosia canicularis and C. himantopus. Complete genetic distinction was recorded only at the Est locus, which was monomorphic with a unique allele in all three species analyzed.
Sequencing revealed a low genetic differentiation between Cheilosia canicularis and C. himantopus (0.5-0.7\% nucleotide difference) and a higher degree of differentiation (5\%) between $C$. orthotricha and the species pair C. canicularis/C. himantopus. Interpreting the differences in the level of divergence in the COI sequence in the C. canicularis group is not straightforward. It is hypothesized that the COI sequence is a slowly evolving gene that may not be a sensitive indicator of speciation (Simon et al., 1994), as illustrated by identical COI sequences in the closely related species Scaeva dignota and S. selenitica (Syrphidae), while the nuclear ITS2 region showed a $7.5 \%$ difference (Ståhls, pers. comm.). The nucleotide variation between Cheilosia canicularis and $C$. himantopus is similar to the observed difference in the COII sequence of single specimens of $C$. canicularis and C. himantopus (0.7\%) (Stuke \& Brückner, 2001).

The genetic differentiation observed between $C$. canicularis and $C$. himantopus was stable and suggested genomic independence of these two species. The presence of one diagnostic locus and five consistently different nucleotide sites in sympatric populations of C. canicularis and C. himantopus (Durmitor, Montenegro) demonstrate that these populations do not exchange genes and are therefore unlikely to be conspecific. The results of morphological analyses support the above. In addition to the morphology of the male genital distiphallus sclerite, and pattern of pilosity on the abdominal tergites in females, only the aristal surface, a more or less clear morphological character, appears to be of diagnostic value in both sexes (Vujić \& Šikoparija, 2001).

\section{Genetic variation within species}

The level of genetic variation within populations of the C. canicularis complex was generally low (Tables 2 and 3). Genetic variability this low is observed only rarely, such as in populations of Melanogaster nuda (Ludoški et al., in press) and certain species of the genus Merodon (Milankov, 2001). Typically, much higher values are recorded for species from the genus Cheilosia, ranging from 0.250 to 0.600 (Milankov et al., 2002a; Ludoški, 2002; Ludoški et al., 2002). Decreased genetic variability in the $C$. canicularis complex could be explained by the genetic system, biology and ecology of the taxon, historic factors such as bottlenecks and founder effect, longlasting isolation, or natural selection and gene flow. However, not enough information is available to define which of the above factors was the most important.

\section{Genetic and phylogenetic relationships}

In spite of the genetic differentiation due to genetic divergence of alleles at the Pgm and Me loci, a high percentage of loci are genetically identical $(I>0.95$; $88.89 \%$ ), which suggests that $C$. himantopus and $C$. canicularis are very closely related. The average value of genetic identity (Nei, 1978) also indicates a low degree of genetic differentiation, with values calculated for conspecific populations of $C$. himantopus $(I=0.937)$ practically identical to those calculated for sympatric populations of C. himantopus and C. canicularis from Durmitor $(I=$ 
0.935). Genetic identity observed among populations of C. himantopus and C. canicularis was higher than values typically observed for closely related species ( $I=$ 0.840-0.898; Ludoški, 2002) and similar to those found among conspecific populations of other species of the genus Cheilosia ( $I=0.928-0.995$; Ludoški, 2002; Milankov et al., 2002a).

The time for the first branching in the Cheilosia group was estimated, based on the number of allelic substitutions (average genetic distance, $D ; \mathrm{Nei}, 1978$ ), to be ca. 2.9-3.5 Mya for $C$. orthotricha and the $C$. canicularis/C. himantopus pair $\left(\mathrm{t}=5 \times 10^{6} \mathrm{D}\right.$; Nei, 1975). Approximate time of divergence within the $C$. canicularis/C. himantopus pair was assessed at ca. 0.3-0.6 Mya. The pairwise sequence divergence in the COI gene, relative to the value of $2.3 \%$ per million years estimated for various arthropod taxa (Brower, 1994), suggests that the speciation events between $C$. orthotricha and the $C$. canicularis/C. himantopus pair occurred ca. 2.3 Mya, and the diversification between $C$. canicularis and $C$. himantopus 0.3 Mya, both figures are in (interestingly) good agreement with those obtained from the allozyme data.

The trees constructed based on the allozyme and COI mtDNA data provide evidence of genetic divergence between the evolutionary distant species $C$. orthotricha and the closely related sister species $C$. himantopus and C. canicularis. Clear differences were interpreted as indicative of species level differentiation.

We hypothesize that $C$. canicularis and $C$. himantopus have split relatively recently, with little time since speciation for nucleotide substitutions to occur and accumulate. It is possible that the speciation was initiated by biological and ecological separation, which did not involve the gene region analyzed in this study.

ACKNOWLEDGEMENTS. The authors wish to thank P. Cederström and $\mathrm{H}$. Bartch for a specimen of Cheilosia himantopus from Sweden. We thank E. Rättel for assistance with DNA sequencing. The authors are also grateful to R. Väinölä, J. Skevington and an anonymous reviewer who provided comments on the manuscript. This work was supported in part by the Ministry of Science and Environmental Protection of Serbia, Grant Number 1770 and Carl Cedercreutz Foundation, Helsinki, Finland.

\section{REFERENCES}

BARKALOV A. 2002: A subgeneric classification of the genus Cheilosia Meigen, 1822 (Diptera, Syrphidae). Entomol. Obozr. 81(1): 218-234. (in Russian, English abstr.)

BLACK W.C. IV. 1997: Biosys-2: A computer program for the analysis of allelic variation in genetics. Colorado State University Ft. Collins, CO.

Brower A.V.Z. 1994: Rapid morphological radiation and convergence among races of the butterfly Helicornus erato inferred from patterns of mitochondrial DNA evolution. Proc. Nat. Acad. Sci. USA 91: 6491-6495.

Clary D. \& Wolstenholme D. 1985: The mitochondrial DNA molecule of Drosophila yakuba: nucleotide sequence, gene organization, and genetic code. J. Mol. Evol. 22: 252-271.

LEVENE H. 1949: On a matching problem arising in genetics. Ann. Math. Stat. 20: 91-94.
LUDOŠKI J. 2002: Evolutionary relationships of the laticornis group of species of the genus Cheilosia Meigen, 1822 (Diptera, Syrphidae). M.Sc. Thesis, University of Novi Sad, Novi Sad (in Serbian, English abstr.)

LudošKi J., Milankov V. \& VuJIĆ A. 2002: Genetic diversity and differentiation between montane populations of Cheilosia urbana (Diptera: Syrphidae). Int. J. Dipterol. Res. 13(2): 135-140.

LudošKi J., Milankov V. \& Vujić A. (in press): Low genetic differentiation among conspecific populations of Melanogaster nuda (Diptera, Syrphidae). Int. J. Dipterol. Res.

MilanKov V. 2001: Evolutionary relationships of the ruficornis and aeneus groups of species of the genus Merodon Meigein, 1803 (Diptera: Syrphidae). Ph.D. Thesis, University of Novi Sad, Novi Sad (in Serbian, English abstr.)

Milankov V., VujIć A. \& LudošKi J. 2001: Genetic divergence among cryptic taxa of Merodon avidus (Rossi, 1790) (Diptera: Syrphidae). Int. J. Dipterol. Res. 12(1): 15-24.

Milankov V., Stamenković J., Vujić A. \& Šımić S. 2002a: Geographic variability of Cheilosia vernalis (Fallen, 1817) (Diptera: Syrphidae). Acta Zool. Acad. Sci. Hung. 48: 255-267.

Milankov V., Vujić A., LudošKi J. \& Šımić S. 2002b: Identification of the species of the melanura group (Syrphidae: Cheilosia) on the Balkan Peninsula. I: Allozyme markers. Vollucela 6: $57-68$.

Milankov V., Vujić A. \& Šımić S. 2002c: Identifying the species of the ruficornis group of the genus Merodon Meigen (Diptera: Syrphidae) using morphological and genetic markers. Studia Dipterol. 9: 319-326.

Munstermann L.E. 1979: Isozymes of Aedes aegypti: Phenotypes, linkage, and use of genetic analysis of sympatric population in East Africa. Ph.D. Thesis, University of Notre Dame, Notre Dame.

Nei M. 1975: Molecular Population Genetics and Evolution. North-Holland, Amsterdam, 290 pp.

NEI M. 1978: Estimation of average heterozygosity and genetic distance from a small number of individuals. Genetics 89: 583-590.

Pasteur N., Pasteur G., Bonhomme F., Catalan J. \& BrittonDavidian J. 1988: Practical Isozyme Genetics. Ellis Horwood, Chichester, $205 \mathrm{pp}$.

Peck L.V. 1988: Family Syrphidae. In Soos A. (ed.): Catalogue of Palaearctic Diptera. Vol. 8. Akademia Kiado, Budapest, pp. 11-230.

Simon C., Frati F., Beckenbach A., Crespi B., Liu H. \& Flook P. 1994: Evolution, weighing, and phylogenetic utility of mitochondrial gene sequences and a compilation of conserved polymerase chain reaction primers. Ann. Entomol. Soc. Am. 87: 651-701.

Sneath P.H.A. \& Sokal R.R. 1973: Numerical Taxonomy. W.H. Freeman, San Francisco, 573 pp.

Speight M.C.D. 2003: Species accounts of European Syrphidae (Diptera), 2002. In Speight M.C.D., Castella E., Obrdlik P. \& Ball S. (eds): Syrph the Net, the Database of European Syrphidae. Vol. 37. Syrph the Net publications, Dublin, pp. $1-213$.

StÅhls G., Stuke J.-H., Vujić A., Doczkal D. \& Muona J. 2004: Phylogenetic relationships of the genus Cheilosia and the tribe Rhingiini (Diptera, Syrphidae) based on morphological and molecular characters. Cladistics 20: 105-122.

Stamenković J., LudošKi J., Milankov V. \& Vujić A. (in press): Genetic differentiation between two populations of Cheilosia himantopus (Panzer, 1798) (Diptera: Syrphidae). Int. J. Dipterol. Res.

STUKE J.-H. 1995: Cheilosia-Larven. Volucella 1: 60-61. 
Stuke J.-H. 2000: Phylogenetische Rekonstruktion der Verwandtschaftsbeziehungen innerhalb der Gattung Cheilosia Meigen, 1822 anhand der Larvenstadien (Diptera: Syrphidae). Studia Dipterol. (Suppl.) 8: 1-118.

Stuke J.-H. \& BRÜCKNER M. 2001: Determination of Cheilosialarvae with DNA sequences (Diptera: Syrphidae). Int. J. Dipterol. Res. 12(3): 151-155.

Stuke J.-H. \& Claussen C. 2000: Cheilosia canicularis auctt. ein Artenkomplex. Volucella 5: 79-94.

Swofford D.L. \& Selander R.B. 1981: BIOSYS-1: A FORTRAN program for the comprehensive analysis of electrophoretic data in population genetics and systematics. J. Hered. 72: $281-283$.
Vusć A. 1996: Genus Cheilosia Meigen and Related Genera (Diptera: Syrphidae) on the Balkan Peninsula. Matica srpska, Novi Sad, 194 pp.

Vujić A. \& Claussen C. 1994: Cheilosia orthotricha, spec. nov., eine weiter Art aus der Verwandtschaft von Cheilosia canicularis aus Mitteleuropa. Spixiana 17: 261-267.

Vujić A. \& ŠIKopariJA B. 2001: Species related to Cheilosia canicularis (Diptera: Syrphidae) on the Balkan Peninsula. Acta Entomol. Serb. (Belgrade) 6(1/2): 107-120.

WeIR B.S. 1996: Genetic Data Analysis II. Sinauer Associates, Sunderland, Massachusetts, $445 \mathrm{pp}$.

Wright S. 1951: The genetical structure of populations. Ann. Eugen. 15: 323-354.

Received December 1, 2004; revised and accepted January 29, 2005 